\title{
Public committees and corporatism: How does Iceland compare to Scandinavia?
}

\author{
Stefanía Óskarsdóttir, Associate Professor, Faculty of Political Science, \\ University of Iceland
}

\begin{abstract}
This paper compares the number of corporatist public committees, appointed by central government, in Iceland and Scandinavia (Denmark, Norway, Sweden). Its main aim is to shed light on where Iceland stands compared to these countries in term of corporatist practices. Scholars view corporatist public committees as the core expression of Scandinavian corporatism and thus well suited for the measurement of corporatism. This study shows that the functional representational channel is an important feature of Icelandic democracy. In Iceland various interest groups are integrated into the democratic process of decision-making and implementation in an institutionalized and privileged manner. This is the essence of corporatism, defined as the institutionalized and privileged integration of organized interests in the preparation and/or implementation of public policies. Moreover, the results show that Iceland is today much more corporatist than the Scandinavian countries; especially, in terms of preparatory corporatism. Already in 1970, it appears that Iceland was more corporatist than Sweden in terms of the number of corporatist committees. The paper also sheds light on sectoral corporatism in Iceland.
\end{abstract}

Keywords: public committees; corporatism; democracy; policy-making.

Icelandic Review of Politics and Administration. Vol. 14, Issue 1. Special issue on power and democracy in Iceland (167-188)

(C) 2018 Contact: Stefanía Óskarsdóttir, stefosk@hi.is

Article first published online May $31^{\text {st }} 2018$ on http://www.irpa.is

Publisher: Institute of Public Administration and Politics, Gimli, Sæmundargötu 1, 101 Reykjavík, Iceland

Stjórnmál \& stjórnsýsla. 1. tbl. 14. árg. 2018. Sérhefti um vald og lýđræđi á Íslandi (167-188) Fræđigreinar

(C) 2018 Tengiliður: Stefanía Óskarsdóttir, stefosk@hi.is

Vefbirting 31. maí 2018 - Birtist á vefnum http://www.irpa.is

Útgefandi: Stofnun stjórnsýslufræđa og stjórnmála, Gimli, Sæmundargötu 1, 101 Reykjavík

DOI: https://doi.org/10.13177/irpa.a.2018.14.1.7

This work is licensed under a Creative Commons Attribution 3.0 License. 


\section{Introduction}

This paper compares the number of corporatist public committees, appointed by central government, in Iceland and Scandinavia (Denmark, Norway, Sweden). Its main aim is to shed light on where Iceland stands compared to these countries in term of corporatist practices. Corporatist public committees are committees, which include at least one representative of interest organizations. Corporatist committees are regarded as the main indicator of corporatism in Scandinavia, defined as the institutionalized and privileged integration of organized interests in the preparation and implementation of public policies (Christiansen et al. 2010, 27; Rommetvedt 2017, 175). This indicator lends itself well to comparative studies on the development of corporatism over time, as well as comparing differences between policy stages and between countries (see below).

Scholars have been researching Scandinavian corporatism for several decades. The research indicates that in the international context Scandinavia used to be rather corporatist, but appears to have become less so in the last three decades (Öberg et al. 2011, 371-374; Rommetvedt 2017, 177). However, it has also been shown that there are differences in corporatist practices in Scandinavia. In particular, Christiansen et al. (2010) have demonstrated this by using corporatist public committees as an indicator.

There has been very limited research done on corporatist practices in Iceland. The few studies that exit are case studies, drawing some comparisons with other countries (e.g. Óskarsdóttir 1995, 1999; Thorhallsson 2010; Jónsson 2014). ${ }^{1}$ The study presented here offers a more comprehensive approach. It does this by applying the same methodology and data on Scandinavia, used by Christiansen et al. in a paper called "Varieties of Democracy: Interest Groups and Corporatist Committees in Scandinavian Policy Making", published in Voluntas in 2010. ${ }^{2}$ In order to make it possible to include Iceland in such a comparison it was necessary to collect and analyse data on the number and composition of public committees in Iceland over time. The paper presents data for three years. 2017, 1985 and 1970.

The data on Icelandic public committees in 1970 and 1985 was collected by analysing the composition and number of public committees, listed in the government's annual reports on boards, committees and councils (Fjárlaga- og hagssýslustofnun 1970-1985), published in 1969 to 1985. The data on the number and composition of public committees in 2017 was collected by visiting the web-sites of all the Icelandic ministries, and with some help from their staff.

The organization of the paper is as follows. First there is a discussion about the meaning of corporatism. It will be shown that there are two traditions when it comes to the study of corporatism; the political economy tradition and the interest group traditions that regards corporatism as a variety of democracy. The approach used in this study falls into the latter tradition, bringing some new light on how democracy works in Iceland. Later sections turn to comparisons between Iceland and Scandinavia. They show that corporatism, measured as the number of corporatist public committees, is today probably the strongest in Iceland of the Nordic countries. Already in 1970, Iceland was more corporatist than Sweden in terms of corporatist public committees. The 
paper also sheds light on corporatism within specific policy sectors (sectoral corporatism) and offers a brief overview of the political landscape in which corporatist political exchanges take place in Iceland.

\section{Corporatism}

\subsection{Earlier developments}

Corporatism has been a contested concept whose meaning has evolved over time. It has historical roots in the administrative structures of some European societies. In earlier times heads of states periodically convened representatives of important economic groups for consultation on matters of state policy and taxation, whose advice they could either adopt or ignore at their own peril. With the adoption of democratic principles of government, the legislative functions of the state were taken over by popularly elected representatives. Also the selection of those heading the executive branch of government became democratically controlled through elections, in which political parties usually play key roles. Elections, and the control of political outcomes by elected representatives, are part of the representational channel of political influence within democratic states. But there are other channels for political influence in democratic political societies. An important channel is the one of functional representation. It involves organized interests, corporations and interest groups in both public policy-making and the implementation of government programs. The configuration and relative importance of these two channels of political influence are among the features which set democratic political systems apart from each other (e.g. Lijphart 1999).

More than fifty years ago Stein Rokkan (1966) noted that the functional-representational channel was a distinctive feature of the Scandinavian political system. This meant that crucial decisions regarding the economy were rarely taken within the political parties or in Parliament because the central arena of politics was the corporatist channel (Rommetvedt 2017, 171). Many subsequent studies similarly concluded that Scandinavian political systems should be classified as corporatist ones (e.g. Schmitter 1979; Armingeon 2002; Lijphart \& Crepaz 1991; Lijphart 1999; Siaroff 1999). However, since the 1980s Scandinavia has moved into a more pluralist direction (Rommetvedt 2017, 191). This change will be the focus of a later section of this paper.

In the 1970s Phillipe Schmitter defined corporatism as "a system of interest representation in which the constituent units are organized into a limited number of singular, compulsory, non-competitive, hierarchically ordered and functionally differentiated categories, recognized or licensed (if not created) by the state and granted a deliberate representational monopoly within their respective categories in exchange for observing certain controls on their selection of leaders and articulation of demands and supports" (1974, 93-94). Schmitter argued that corporatism should be regarded as a system of interest and/or attitude representation, a particular modal or ideal-typical institutional arrangement for linking the associational organized interests of civil society with the decisional structures of the state; pointing out that as such corporatism is one of several 
possible modern configurations of interest representation, of which pluralism is perhaps the best known alternative $(1974,86)$.

Schmitter's work, initially focused on corporatism in authoritarian countries (Portugal and Brazil). But the need to distinguish corporatist practices in democratic countries from those in undemocratic ones, prompted scholars like him to define corporatism in such a way that it was also applicable to democratic political systems. However, corporatism in democratic societies seemed at the time to require a prefix. Thus corporatism in democratic societies became alternatively known as neo-corporatism, liberal corporatism or societal corporatism, to name maybe the most frequently used terms. Current literature, however, seems to be comfortable with using simply the term 'corporatism'.

\subsection{Two research traditions}

According to Christiansen et al., research on corporatism may roughly be divided into two traditions: the political economy tradition and the interest group tradition. They point out that in the political economy tradition corporatism is regarded as a variety of capitalism whereas the interest group tradition views corporatism as a particular type of liberal democracy $(2010,25-26)$. The core interest of the political economy school is how coordination among important economic actors - labour, capital, and state - takes place in capitalist societies. Therefore, scholars working within this tradition tend to focus on corporatism at the macro-level, sometimes simply defining corporatism as macro-level policy concertation; meaning that representatives of the state and major interest organizations are brought together to seek common ground on contentious issues (co-operation). Related to this, they study the way economic interests are organized, how they interact with state actors, and the effects of these variables on macro-economic performance. They also focus on certain structural variables (such as union membership, the strength of peak organizations, the degree of centralization of wage bargaining, the strength of state actors, etc.) as well as on certain process variables (bargaining, concertation, type of relations between business, labour, and the state), which are then related to certain outcomes (such as economic flexibility, strike activity, unemployment and inflation, dispersion of wages, etc.) (Christiansen et al., 2010, 25-26). The opposite of corporatism in the political economy tradition is pluralistic bargaining, disorganized capitalism, or liberal market economies.

The other tradition, the interest group tradition, sees corporatism as part of liberal democracy rather than capitalism. Here the focus is on the workings of democracy and political processes involving the state and interest groups, interest organizations and corporations. Viewed through this lens, corporatism is the opposite of pluralism (Schmitter 1974; Rommetvedt 2003, 2005), the numerical channel of democratic representation (Rokkan 1966), or parliamentary democracy and legalism (Hermansson et al. 1999) (Christiansen et al. 2010, 26). Lijphart's (1999) classification of democracies is a clear example of this tradition. To him corporatism is an essential part of consensual democracy, which differs from majoritarian democracy in its reliance on coalition building and power sharing. Others have asserted that corporatism is an inseparable attribute of negotiation democracy (Armingeon 2002). 
The political economy tradition dominated early studies of corporatism; typically focusing on either incomes policies or industrial policies. It was also broadly assumed that corporatism involved a fusion, within a closed relationship, of the processes of interest representation and policy implementation. In other words, it was believed that within the corporatist framework privileged interest organizations participate both in policy preparation/formulation as well as in policy implementation (Christiansen et al. 2010, 26-27). Empirical research has, however, shown that this is not necessarily the case. Thus it is quite possible to have more corporatism in policy formulation and less in implementation or vice versa. ${ }^{3}$

The macro-level political economy approach has also been criticized for being overly static and therefore unsuitable for understanding how corporatism may evolve over time. In a review article on the evolution of the concept of corporatism, Molina and Rhodes (2002) argued that an "excessively structural-functionalist interpretation of corporatism led many wrongly to predict its demise as a form of policy making, and that an understanding of its persistence and new manifestations today must resurrect and strengthen some early, recently neglected insights into processes of political exchange" (Molina \& Rhodes 202, 305). Citing the works of Lehmbruch (1984), Regini (1984) and others, they maintained that corporatism is best understood as a process of political exchange where organized interest groups are integrated into the public policy-making process (Molina \& Rhodes 2002, 321).

When treated as a form of an integrated political exchange, corporatism becomes a variable, which can change over time and is not restricted to certain policy fields. This is important, according to Molina and Rhodes, because "there exists an array of corporatist phenomena, ranging from the intensive to the extensive and from the highly to the weakly integrated, encompassing manifestations that are horizontally inclusive or exclusive and vertically shallow or deep. Particular instances of corporatism do not remain static; they evolve along these dimensions, as witnessed by developments in many European countries over the past decade or so" (Molina \& Rhodes 2002, 324).

Corporatism, understood in terms of an exchange relationship, is not confined to the labour market and negotiations on wages, profits, and economic policy. This has been borne out by empirical research, which has shown that corporatism may be found in any policy area and it may also change over time; showing that corporatism, like pluralism, is a continuous variable that is subject to changes over time (Rommetvedt 2017, 174).

The political exchange nature of corporatism is further elaborated by Öberg et al. (2011). They view corporatism as a type of political exchange that takes place in institutionalized arenas in which each actor controls resources that the others desire. As such it can take place in a multitude of policy areas. A corporatist exchange assumes that organizations control internal opinions, while the state controls authoritative decisionmaking. "An exchange does not need to be symmetrical (however defined), but it can be realized only when the state offers policies of interest to the organizations which, in return, provide tacit consent, approval or active support of government policy that is of interest to the state" (Öberg et al. 2011, 367). 


\subsection{Democratic integration}

Scholars who study corporatism as a variety of democracy (exchange relationship) are specifically looking into how interest groups are integrated into the democratic process of decision-making and implementation. Accordingly, Christiansen et al. (2010) maintain that in functional or institutional terms, the central and minimal characteristic of corporatism is the integration of certain organized interests into the policy process. Accordingly, they define corporatism as the institutionalized and privileged integration of organized interests in the preparation and implementation of public policies (Christiansen et al. 2010, 27).

The definition focuses attention on the integration of organized interest in the democratic process of preparing and implementing policy. The authors point out that the presence of corporatism does not mean that relations between partners are always harmonious and without political conflicts. "The integration may be associated with process attributes like bargaining, compromising, or concertation. But even these attributes cannot be taken for granted. Negotiations may break down, compromises may be impossible, and concertation may never result" (Christiansen et al. 2010, 27).

Following the classical understanding of corporatism, their definition clearly emphasizes the institutional nature of the interest intermediation process as well as the privileged access of a limited number of interest organizations. Accordingly, corporatism can be recognized by the fact that it is institutionalized and has been set up by the authorities. But once it has been established the initiative for action can be taken both by interest organizations as well as by public authorities. The definition also emphasizes the importance of distinguishing between the separate phases of the policy process - policy preparation and implementation. This is important because corporatism may be found in several phases of the policy process, but not necessarily in all phases at the same time. Finally, their definition also takes into account that corporatism may be found in any policy area (Christiansen et al. 2010, 27).

\section{Corporatist public committees}

\subsection{Public committees as a measure of corporatism}

Based on the definition of corporatism as the institutionalized and privileged integration of organized interests in the preparation and implementation of public policies, corporatism is institutionalized, has been set up by the authorities and involves the privileged access of a limited number of interest organizations. In Scandinavia public committees and commissions with interest group representation have been seen as the foremost institutional expression, and therefore the best indicator, of corporatism (Christiansen et al. 2010, 29; Rommetvedt 2017, 175).

Access to public committees is a formalized tool of interaction between groups and government actors. Public committees are highly institutionalized, having room for a limited number of members, and consequently only some privileged organizations can be represented. Some of the public committees are appointed on a temporary basis while others are permanent. Members may include representatives of various interest 
organizations, civil servants, experts and sometimes politicians (Rommetvedt 2017, 174175).

One of the drawbacks of using public committees as an indicator of corporatism, according to Christiansen et al., is that it only measures formal corporatism and not the informal connections and ties. However, they find this to be a minor problem because "formal and informal corporatism tend to go together if they do not correlate perfectly" (Christiansen et al. 2010, 29). Thus they point out that groups with membership in public committees are generally better equipped to affect political decisions. The second drawback is that, certainly, not all public committees are equally important. However, Christiansen et al. believe that this problem is overcome by looking at the number of corporatist public committees across policy sectors, as well as over time. In that way it is possible to see trends over time and between countries; trends which can be backed by case studies. They point out that with Danish data, "public committees as the indicator of corporatism has been shown to correlate nicely with other measures of corporatism" (Christiansen et al. 2010, 28-30). To sum up, by using public committees as an indicator of corporatism facilitates comparisons across countries, time periods and policy fields. Case studies focusing on selected policy sectors are unable to achieve this, according to Christiansen et al. Case studies cannot, for example, answer the question to what extent the selected cases are representative for the general development in corporatist policy making (Christiansen et al. 2010, 28).

Public committees are considered to be corporatist if they include at least one representative of an interest organization (Christiansen et al. 2010; Rommetvedt 2017). This includes all types of interest organizations, not only representatives of unions or employers' associations. This is important because in the interest group tradition the aim is to understand how interest groups are integrated into the public policy-making process. Empirical research has shown, for example, that public interest groups and groups representing users of welfare services are also participants in corporatist institutions (Binderkrantz \& Christiansen 2015, 6).

In the next section we turn to the comparison of corporatist public committees in Iceland and Scandinavia; relying on the definition of corporatism offered by Christiansen et al. (2010) as well as their general methodology.

\subsection{Corporatist public committees in Iceland and Scandinavia}

For non-Icelandic readers it should be noted that Iceland is a very small state, with a population of about 350,000. Before it got home rule in 1904, Iceland was an integral part of the Danish administrative system. After it became a sovereign state in 1918 its developing administrative and legal systems remained influenced by this historical legacy. In the century that has since passed state capacities have grown. Today Iceland has a well-developed welfare state providing extensive services to its population. The national public administrative system is organized around a dozen or so government ministries as well as various state institutions and enterprises.

The Icelandic administrative system has relied extensively on the use of public com- 
mittees, councils and boards appointed by central government (hereafter public committees). These public committees serve various functions; including preparing and advising on policy, implementing policy, granting licenses and certifications, adjudicating, distributing grants or other financial resources and governing public institutions. Already at the end of WWII Iceland had a relatively large number of public committees. Thus in 1948 it had more than 150 public committees appointed by central government (Guðmundsson 1949, 3). In 1970 the number of public committees had grown to 371, to 465 in 1975 and to 548 in 1980. The number of public committees continued to rise in Iceland until 2000 when there were 910 public committees. In 2005 the number was 800 and by the end of 2017 Iceland had 603 public committees.

In comparison, Denmark had 622 public committees in 1965, appointed by central government. In 1975 there were 640 public committees and 425 in 1980. However, in 2005 the number of Danish public committees was down to 204 committees (Christiansen et al. 2010, 31-33).

According to Thesen and Rommetvedt, Norway had 954 public committees in 1966 but this number also included committees appointed by local and regional authorities (Thesen \& Rommetvedt 2009, 39). There is no data available for the number of Norwegian public committees, appointed only by central government prior to 1983 , but in that year there were 401 Norwegian public committees, appointed by central government. By 2005 the number was down to 153 public committees (Christiansen et al. 2010, 31-33). Like in Denmark and Norway, the number of public committees has also declined over time in Sweden. However, the number of Swedish public committees was never as high as it was in Norway and Denmark. In 1970 Sweden had 217 Swedish public committees, 280 in 1980, 264 in 1990 and 192 in 2004 (Christiansen et al. 2010, 31-33).

Over half of all public committees in Denmark in the 1960s and 1970s were corporatist. This ratio rose somewhat with the dwindling number of public committees. Nevertheless, the total number of corporatist public committees also declined until the 1990s when their number stabilized. In 1975 Denmark had 368 corporatist public committees, 230 in 1985, 156 in 1990 and 166 in 2005. ${ }^{4}$

The same development occurred in Norway; with a dwindling number of public committees, the ones that were appointed were more likely to include representatives of interest organizations. According to Christiansen et al. (2010), Norway had 281 corporatist public committees in 1983, 218 in 1993 and 94 in 2005 (Christiansen et al. 2010, 31-33). In Sweden, on the other hand, the drop in the number of corporatist public committees meant that the public committees that remained in place were less likely than before to include representatives of organized interests (see Table 1). Sweden had 87 corporatist public committees in 1970, 121 in 1980, 68 in 1990 and only 60 such committees in 2004. 
Table 1. Number of all public committees and public committees with representation from interest organisations by selected years and countries

\begin{tabular}{|c|c|c|c|c|}
\hline Year & Iceland & Denmark & Norway & Sweden \\
\hline 1970 & 365 & $\begin{array}{c}640 \\
(1975)\end{array}$ & & 217 \\
\hline with i.o. & 154 & 368 & & 87 \\
\hline 1985 & 557 & 317 & $\begin{array}{c}401 \\
(1986)\end{array}$ & $\begin{array}{c}280 \\
(1980)\end{array}$ \\
\hline with i.o. & 193 & 230 & 281 & 121 \\
\hline 1990 & 562 & 204 & $\begin{array}{c}317 \\
(1993)\end{array}$ & 264 \\
\hline with i.o. & $\mathrm{n} / \mathrm{a}$ & 156 & 218 & 68 \\
\hline 2005 & 800 & 204 & 153 & $\begin{array}{c}192 \\
(2004)\end{array}$ \\
\hline with i.o. & $\begin{array}{c}n / a \\
(266+)\end{array}$ & 166 & 94 & 60 \\
\hline 2017 & 603 & $\mathrm{n} / \mathrm{a}$ & $\mathrm{n} / \mathrm{a}$ & $n / a$ \\
\hline with i.o. & 296 & $\mathrm{n} / \mathrm{a}$ & $\mathrm{n} / \mathrm{a}$ & n/a \\
\hline
\end{tabular}

The numbers for Denmark, Sweden and Norway are found in Christiansen et al. 2010, 31-33.

In Iceland, by contrast, there are now both more public committees, as well as corporatist public committees, than there were in 1970 and 1985. At the end of 2017 there were 296 corporatist public committees in Iceland, compared to about 154 in 1970 and 193 in 1985. In 2017 almost half of all public committees included representatives of interest organization, whereas in 1970 a little over $40 \%$ of public committees included representatives of interest organizations, but only a third of the committees in 1985 appears to have had interest representation.

The newest available published numbers for Scandinavia are from 2004/2005. For these years we do not yet have comparable data for Iceland. However, an educated guess would be that Iceland may have had somewhere between 266 to 400 corporatist public committees, given that there were 800 public committees at the time. This guess assumes that no less than a third of the 800 committees, and maybe as many as a half of them, included representatives of organized interests. Even the lower number means that Iceland had in all likelihood many more corporatist public committees than Denmark, Norway and Sweden at the same time.

To sum up. The numbers presented in this section show that Iceland appears to have become the most corporatist of the Nordic countries in the new century, using the measure of corporatist public committees. Already in 1970 Iceland was more corporatist than Sweden. Then Iceland had some 154 corporatist committees compared to 87 corporatist Swedish committees. Also, by 1985 Iceland was not so far behind Norway and Denmark in terms of its total number of corporatist public committees. In the next 
section, the attention is turned to the question of how Iceland compares to the Scandinavian countries in terms of the number of corporatist preparatory and implementation public committees. As was mentioned earlier in this paper, Christiansen et al. (2010) find it useful to differentiate between preparatory public committees and implementing public committees in order to get a more nuanced picture of corporatist practices and how they develop over time (Christiansen et al. 2010).

\subsection{Preparatory and implementation corporatism}

Preparatory committees are those committees that among other things provide advice and help prepare policy and legislative initiatives, while implementation committees include boards, councils, commissions and committees responsible for distributing public goods and services and making other authoritative decisions. Implementation committees are likely to have a formalized and delimited authority to make public decisions.

By differentiating between the two types of public committees, Christiansen et al. were able to detect different patterns in the Scandinavian countries. They showed that the preparation of policy through corporatist bodies has declined significantly in Denmark and Norway since the 1970s and 1980s. In Sweden, however, it was never a widespread practice to assign the preparation of policy to corporatist public committees. This is one of the interesting findings of their comparative study. Their results also demonstrated that implementation corporatism declined significantly in Norway after 1980, but less so in Sweden. Finally, another interesting finding of Christiansen et al. is that implementation corporatism is as widespread in Denmark today as it was in the 1980s, although it declined significantly during the 1970s (Christiansen et al. 2011, 33).

When we look at the numbers for Iceland we see a different trend. In Iceland the number of preparatory corporatist public committees has increased since the $1970 \mathrm{~s}$ and 1980. Moreover, there are now more corporatist preparatory committees in Iceland than there were in the Scandinavia countries during their heydays of corporatism. This is illustrated in Table 2. In 1970 Iceland had 54 corporatist preparatory committees, compared to 21 in Sweden and 156 in Denmark (1975) (data is not available for Norway for this time). In 1985 Norway had 36 corporatist preparatory committees compared to 67 such committees in Iceland and 117 in Denmark. There are no numbers for Sweden available for that year. However, in 1990 Sweden had only 6 corporatist preparatory committees (Christiansen et al. 2010, 31). Finally, in 2005 Denmark had only 39 corporatist preparatory public committees, whereas Sweden (2004) and Norway had 13 and 12 respectively. ${ }^{5}$ In comparison, Iceland had 180 corporatist preparatory committees in 2017, which again is a larger number of such committees than Denmark had in the 1970s. ${ }^{6}$ Moreover, as Table 2 shows, already in 1985 Iceland had more corporatist preparatory committees than Norway and Sweden.

The numbers for Scandinavia in Table 2 clearly indicate that corporatist preparatory committees are now somewhat rare in Scandinavia. This is consistent with a series of qualitative studies, which have documented that "corporatist arrangements are not as central to policy-making as in previous decades, and that unions in particular play a 
less privileged role (Blom-Hansen 2001; Christiansen \& Klitgaard 2010; Klitgaard \& Nørgaard 2014)" (Binderkrantz \& Christiansen 2015, 9). Again, this is not the case in Iceland, which now has many more corporatist preparatory committees than it did in both 1970 and 1985.

Table 2. Number of preparatory public committees etc. with members from interest organizations in selected years

\begin{tabular}{lcccc}
\hline Year & Denmark & Norway & Sweden & Iceland \\
\hline $1970 / 1975$ & 156 & & 21 & 54 \\
1985 & 117 & 36 & $\mathrm{n} / \mathrm{a}$ & 67 \\
$2004 / 2005$ & 39 & 12 & 13 & $\mathrm{n} / \mathrm{a}$ \\
2017 & & & & 180 \\
\hline
\end{tabular}

Figures for Denmark, Norway and Sweden are from Christiansen et al. 2010, 31.

A closer look at implementation corporatism shows that Iceland has about as many implementation corporatist public committees in 2017 as it had in 1970, around 100 committees. In Norway the number was down from 204 in 1984 to 82 in 2005. Denmark had 127 corporatist implementation committees in 2005 compared to 212 in 1970. ${ }^{7}$ In Sweden the number was down to 47 compared to 66 in the 1970s. According to this, Sweden now stands out with relatively few implementation corporatist public committees. Denmark, on the other hand, has the greatest number, followed by Iceland and Norway (see Table 3).

Table 3. Interest group representation on implementation bodies (agency boards, committees, etc.) by selected years

\begin{tabular}{lllll}
\hline Year & Denmark & Norway & Sweden & Iceland \\
\hline $1970 / 1975$ & 212 & n/a & 66 & 100 \\
1985 & 113 & 204 & n/a & 126 \\
$2004 / 2005$ & 127 & 82 & 47 & n/a \\
2017 & & & & 101 \\
\hline
\end{tabular}

Figures for Denmark, Norway and Sweden before 2010 are from Christiansen et al. 2010, 33.

To sum up. The numbers for Iceland show that the preparation of policy through corporatist bodies has increased significantly in Iceland since 1970/1985 while the number of corporatist implementation committees remains similar to then. In 1970 Iceland had almost twice as many implementation committees as it had preparatory committees (100/54). But in 2017 this had changed. Then it had 180 corporatist preparatory committees, compared to 101 corporatist implementation committees and 15 corporatist committees that did both. In other words, the growth in the number of Icelandic corporatist public committees since the 1970s and 1980s is the result of an explosion in the 
number of corporatist preparatory committees. Prior to the 1990s, Denmark also had many more corporatist preparatory committees than implementation committees. Such committees have now become rare in Scandinavia as this section has demonstrated.

\subsection{Institutionalization of Icelandic public committees}

A third of all Icelandic public committees in 2017 are required by law, regulations or agreements to include representatives of interest organization. Moreover, a great majority of the corporatist public committees were required to do so; namely, 204 out of the 296 corporatist public committees. However, there are interesting differences between corporatist public committees depending on whether they were involved with policy preparation or implementation. Thus all but two of the corporatist implementation public committees were legally required to include representatives of interest organizations, compared to a little over a half of the corporatist preparatory public committees. These numbers are a clear indication of the institutionalization of corporatist practices in Iceland.

However, the large number of ad hoc (short term) corporatist preparatory public committees is also interesting. It suggests that ministers/ministries find it useful to include representatives of organized interests on such committees, even though they are not required to do so by laws, regulations or agreements. This in turn is evidence of the fact that organized interests have resources that give them power to engage in corporatist exchanges with the state. It also shows a general willingness to participate in corporatist political exchanges (see more later).

In $197036 \%$ of all Icelandic public committees were based on laws or resolutions passed by Parliament (Alping $)$. In 1975 the percentage was 34\%, 31\% in 1980 and 35\% in 1985 (Kristinsson 1994, 105). Unlike the figures for 2017, these numbers do not tell us how many of the committees were legally required to include representatives of organized interests. However, Kristinsson (1994) offers some partial answers to this question by pointing out differences between ministries in terms of legal requirements to include representatives of interest organizations. Thus in 1989-1990, ministers heading ministries concerned with industry and production were obligated to appoint interest group representatives to more than $60 \%$ of the public committees to which they appointed members. ${ }^{8}$ Next came ministers, heading public service ministries. They were required to appoint interest representatives to about $50 \%$ of the public committees to which they appointed members. The corresponding figure for ministers, heading ministries concerned with the co-ordination of public affairs, was about 30\% (Kristinsson 1994, 108-110). These are interesting differences that point towards the prevalence of corporatism in certain sectors. In the next chapter, attention is turned to sectoral corporatism in Iceland and its evolution over time.

\subsection{Sectoral corporatism in Iceland}

Empirical research has shown that corporatism can be found in any policy area. This section presents data on sectoral corporatism in Iceland in 1970, 1985 and 2017. It does 
this by showing the percentage of corporatist public committees within particular governmental ministries as well as their absolute numbers. Both are good indicators of the existence of sectoral corporatism.

In 1970 the highest percentage of corporatist committees was to be found among those appointed by the minister of social affairs (64\%), followed by the Ministry of the Prime Minister $(58 \%)^{9}$. Next came the Ministry of Commerce (50\%); Ministry of the Fisheries (47\%); Ministry of Agriculture (47\%) and the Ministry of Education (43\%), which both then and later had the highest number of public committees. The smallest percentage of corporatist public committees in 1970 was found within the Ministry of Transportation/Communications (15\%) and the Ministry of Industry (24\%).

In 1985 the Ministry of the Fisheries had become the most corporatist in terms of the percentage of public committees with interest representation. Then $73 \%$ of public committees appointed by the minister of the fisheries were corporatist. Next came public committees under the Ministry of Social Affairs (58\%); then public committees under the Ministry of Agriculture (45\%); public committees under the Ministry of Transportation (43\%); and public committees under the Ministry of Health and Social Insurance $(42 \%)$. The least corporatist appointments were to be found at the Ministry of Industry (10\%); the Ministry of Foreign Affairs (11\%); and the Ministry of the Prime Minister $(16 \%)$. However, only about $1 / 3$ of the numerous (162) public committees of the Ministry of Education were corporatist at the time.

In absolute terms, the highest number of corporatist public committees in both 1970 and 1985 was found within the Ministry of Education; 44 compared to 52 in 1985. Next came the Ministry of Social Affairs with 27 corporatist public committees in 1970, while the Ministry of the Fisheries had 14 corporatist public committees. In 1985 the Ministry of the Fisheries was in second place, with 24 corporatist committees. Next came the Ministry of Health and Social Security with 22 corporatist public committees, followed by the Ministry of Social Affairs that had 21 corporatist public committees. In 1985 the Ministry of Agriculture had 13 corporatist public committees, compared to 7 in 1970 .

How are these numbers today? Icelandic ministries were reorganized in 2012. Instead of separate ministries of the fisheries, agriculture and industry the ministries were merged into only one ministry, the Ministry of Industry and Innovation. In 2017, 53\% of the public committees of the new Ministry of Industry and Innovation (Atvinnu- og nýsköpunarráduneytid) included members of interest organizations. The highest percentage of corporatist public committees in 2017 was, however, found among public committees appointed by the minister of transportation and local government $(63 \%)$, followed closely by the Ministry of the Environment and Natural Resources (60\%). Next come the Ministry of Health and Welfare (57\%) the Ministry of Industry and Innovation (53\%) and the Ministry of Education and Culture (46\%). The least corporatist are the Ministry of Finance and Economic Affairs (26\%), the Ministry of Justice (30\%) and the Ministry of the Prime Minister (38\%).

Table 4 shows the number of public committees and corporatist public committees 
in 2017 broken down by ministries. It demonstrates that the highest number of corporatist public committees in 2017 was found within the Ministry of Education and Culture (90), followed by the Ministry of Health and Welfare (66) and the Ministry of Industry and Innovation (47). Interestingly, this is not so different from what was already the case in 1970 and the 1985. Therefore, it may be concluded that the most corporatist policy sectors in Iceland are, and have been, those that deal with public services (education, health and social affairs including local government) and the traditional industries (agriculture and the fisheries). ${ }^{10}$

Table 4. Number of Icelandic public committees at the end of 2017, by ministry and composition

\begin{tabular}{lcc}
\hline Ministry & Corporatist & Expert/Admin \\
\hline Industry and Innovation & 47 & 39 \\
Justice & 12 & 24 \\
Prime Minister & 5 & 8 \\
Transportation and local government & 24 & 10 \\
Environment and natural resources & 34 & 23 \\
Health and Welfare & 66 & 46 \\
Education and Culture & 90 & 104 \\
Finance and Economic Affairs & 15 & 42 \\
Foreign Affairs & 2 & 0 \\
\hline Total & 296 & 296 \\
\hline
\end{tabular}

It is, for example, interesting that of the 47 corporatist public committees working for the Ministry of Industry and Innovation in 2017, 22 committees included representatives from the Icelandic Association of Farmers (Bandasamtök Íslands). This is a clear indication of the strong position this interest organization has within the ministry. Also, 8 of its corporatist committees included representatives of the Iceland Fisheries (Samtök fyrirtakja i sjávaruitvegl), which represents the fishing industry.

Finally, Table 4 also shows the number of public committees which included only "experts". In 2017 there were as many such "expert committees" as committees with representatives of interest organizations. "Experts" are individuals who appear to be chosen to sit on public committees due to their qualifications and expertise. They work either within the ministries, at other government institutions or come from the outside of the government. Such experts may have close ties to their field of expertise, but they are not representing that field directly. Likewise, representatives of interest organizations may also be "experts" but they sit on committees as representatives of their organizations. The Ministry of Education, followed by the Ministry of Health and Welfare and the Ministry of Finance and Economic Affairs, had the highest number of "expert" committees in 2017. 


\section{The corporatist context}

The findings of this paper show that corporatism is relatively robust in Iceland today compared to Scandinavia. Although it is outside the scope of this paper to investigate what explains the prevalence of corporatism in Iceland, the interesting findings warrant a brief explanation of what might be the contributing factors. Öberg et al. (2011), provide a useful framework for understanding the context of corporatism. As was noted earlier in this paper, they view corporatism as a type of political exchange that takes place in institutionalized arenas in which each actor controls resources that the others desire. The exchanges between the state and organized interests require that one party is in control of resources in which the other is interested. A corporatist exchange assumes that interest organizations control internal opinions, while the state controls authoritative decision-making (Öberg et al. 2011, 367). Moreover, interest organizations usually have within their ranks a wide range of expertise pertinent to solving problems at hand.

According to Öberg et al. (2011), a corporatist political exchange (corporatism) requires the state, as well as interest organizations, to have a strong mandate to engage in exchanges. It also presupposes a high degree of unity, mobilization of relevant assets and corporatist-friendly attitudes on both sides of the exchange. "Without these features, actors are not trustworthy exchange partners" (Öberg et al. 2011, 368). Mandate means that the state has the ability to control legislation at central government level (sovereignty), whereas for interest groups it means that they have to be accepted as the representative of that specific interest. Unity refers to the ability of the government to gather support from a parliamentary majority, while interest groups have to be sufficiently cohesive to represent their members effectively. Such a unity it important because both parties "must retain a capacity for making binding commitments if credible exchange is to take place" (Öberg et al. 2011, 368).

The partners, respectively, also need to possess relevant assets. Even a cohesive and united government, as Öberg et al. point out, will be constrained in its ability to offer favourable and credible policy deals when it is under economic pressure. Similarly, an interest group must be able to mobilize members who are willing to support leadership decisions made in corporatist exchanges and, ultimately, to back the government involved. Finally, leaders on all sides need to share some commitment to corporatist practices (Öberg et al. 2011, 369). The authors maintain that the weakening of the mandate, unity, assets and underlying values explain the decline of corporatist practices in Scandinavia.

This appears not to have been the case in Iceland so far. The great number of Icelandic public committees, which include members of interest organizations, suggests that both the government as well as interest organizations find it useful to engage in corporatist exchanges; a fact which further fuels the will to engage in such exchanges. Moreover, this also suggests that the partners involved are perceived to have the mandate and the necessary means (unity, assets) to engage in corporatist exchanges leading to favourable results.

Looking first at the state and what it brings to the table; the government controls legislation, as well as the state budget, due to the fact that it enjoys the support of the 
parliamentary majority. Striking political bargains with the Opposition is usually not required in order to pass legislation, since minority governments are the exception. Research has also shown that party cohesion, like in other parliamentary systems, is high within Parliament (Alping ) (Kristinsson 2011; Indriðason \& Kristinsson 2015). Government legislative proposals and policies are therefore very likely to have the backing of the parliamentary majority supporting the government. This minimizes the influence of the Opposition on policy-making. Nevertheless, any government values securing societal and political support for policy initiatives and implementation. Both may be achieved by involving interest groups in the policy process (preparation and implementation). For this reason, the functional channel of representation comes into play; not least because major interest groups in Iceland represent large segments of society (see more below).

Limited administrative capacities may also enhance the attractiveness, for the government, of engaging in corporatist exchanges. Iceland has a very small public administration, relating to the fact that it has a very small population. Yet, it has to perform many of the same tasks as larger public bureaucracies do but with fewer resources. Therefore, from the vantage point of the government it makes sense to extent its capacities by involving interest groups, and experts working on their behalf, in the preparation and implementation of policy. This practice makes it, for example, unnecessary to permanently employ more experts. In modern day Scandinavia, the capacities of the public administration have expanded, thus reducing the need to involve outside experts on an ad hoc basis. Iceland also sets itself apart from its Scandinavian counterparts in that it has only two levels of government; the national and local levels with no regional level. Moreover, Iceland like Norway remains outside of the European Union, although both are members of the European Economic Area.

It is likely, that the differences in the size of the bureaucracy, as well as some differences in the organization of the administrative system, may in some ways contribute to the fact that Iceland has today far more corporatist public committees than its Scandinavian counterparts. But without large and well organized interest organisations, corporatist exchanges would be fruitless. In this regard, Iceland ranks high. It has a number of major, well organized interest groups that have representational monopoly, turning them into important political players. For example, the unionization of Icelandic employees is one of the highest in the world. Over $80 \%$ of employees are members of trade unions, compared to less than $70 \%$ in Denmark and Sweden and 55\% in Norway. The high union density in Iceland is the result of the widely enforced system of closed shop. It ensures that jobs and welfare benefits, such as unemployment benefits, sick leaves and parental leaves, are secured through union membership. Finally, Icelandic trade unions are organized according to craft rather than sectors, which gives them a reach across various industrial sectors.

Although the right to bargain rests with individual unions, the Icelandic Confederation of Labour (ASÍ) has a strong position within the labour movement. According to its website, its ,role is to promote the interests of its constituent federations, trade unions and workers by providing leadership through co-ordination of policies in the fields of 
employment, social, education, environment and labour market issues. ASI represents the trade union movement at various levels of the government on issues such as labour law, employment and social policy, vocational education and training and occupational safety" (ASÍ n.d.). The description shows the extensive scope of the operations of the Icelandic Confederation of Labour. It is also mirrored by the fact that at the end of 2017 it had representatives on 52 public committees, appointed by central government.

Unions in the public sector also have a strong representation on public committees. A case in point is the fact that the Icelandic Teachers' Union (KÍ) was represented on 22 public committees in 2017, the Federation of State and Municipal Employees (BSRB) was represented on 27 public committees and the Icelandic Confederation of University Graduates (BHM) had representatives on 18 public committees. Interest organizations representing welfare recipients, students and parents are also represented on various public committees. For example, the Association of Disabled People (Örykjabandalagið) had representatives on 8 public committees in 2017 while the Association of the Elderly (Landssamband eldri borgara) had representation on 5 public committees.

Employers, for their part, are also well organized and influential. Their main organization is the Icelandic Confederation of Enterprise (SA) which includes about 2000 companies that employ about $70 \%$ of the Icelandic workforce. ${ }^{11}$ The Icelandic Confederation of Enterprise bargains on the behalf of all these companies (SA n.d.). Representatives of the Confederation of Icelandic Enterprise were found on 61 public committees in 2017. Particular sectors within the confederation are well organized as well. This includes the Federation of Icelandic Industries (SI), Fisheries Iceland (SFS), the Federation of Energy and Utility Companies (Samorka) and the Federation of Tourism (SAF). Each of these organizations represents the majority of producers within their respective sectors. At the end of 2017 Fisheries Iceland had representatives on 14 public committees, the Federation of Energy and Utility Companies had representatives on 10 public committees, the Federation of Tourism had representatives on 9 public committees, and the Federation of Icelandic Industries had representatives on 8 public committees etc.

The Icelandic Farmers 'Association (Bendasamtök Íslands) is made up of 16 organizations representing farmers in different fields of agriculture. Until 2017 the state imposed, and collected, a tax (búnaðargjald) on farmers which was used to fund the Icelandic Farmers 'Association and related activities. The practice was yet another indication of the strong corporatist ties between the state and the agricultural sector. ${ }^{12}$ Also, in 2017 the Icelandic Farmers Association had representatives on 26 public committees. In addition, its member organizations had representatives on several public committees as well.

Many more interest organizations are represented on Icelandic public committees. Among them are the Icelandic Association of Municipalities (Samband islenskra sveitarfélaga) that has representatives on close to 100 public committees. In comparison, the Iceland Nature Conservation Association (Náttúruverndarsamtök Íslands) has representatives on 10 corporatist public committees.

This section has offered a brief overview of the political landscape in which cor- 
poratist political exchanges take place in Iceland. There is a rich history of corporatist practices in Iceland still unexplored and undocumented. A further research into this history can provide deeper insights for those theorizing about corporatism and democratic practices. But as the results of this paper show, the state finds it useful to engage major interest organizations in political exchanges in order to secure advice, acceptance and compliances to state policies and implementation. Interest organizations, likewise, are willing to participate in such exchanges in the hope that it helps promoting their interests and goals. The large number of public committees, appointed by central government, is a clear indication of the embeddedness of corporatist practices in Iceland. These committees provide the institutional, formal setting for the state and interest organizations to engage in political exchanges. Moreover, the great majority of these corporatist committees are set up by laws, regulations or agreements.

\section{Conclusions}

Very little comparative research exists on how Iceland compares to other countries in terms of corporatism. The research presented in this paper addressed this lack of knowledge by comparing the number of corporatist public committees, appointed by central government, in Iceland and Scandinavia (Denmark, Norway, Sweden), in order to determine where Iceland stands in term of corporatist practices. Corporatist public committees are committees, which include at least one representative of interest organizations. They are regarded as the main indicator of corporatism in Scandinavia, defined as the institutionalized and privileged integration of organized interests in the preparation and implementation of public policies (Christiansen et al. 2010, 27). The definition emphasizes the institutional integration of interest groups into the democratic process. The focus on privileged access in the definition also implies that some interest groups are given access to the institutionalized corporatist channels while others are excluded. Moreover, the distinction between policy formulation and implementation in the definition opens up for the possibility that the degree of corporatism may vary between the two phases of the policy process (Rommetvedt 2017, 173).

The paper was inspired by the study of Christiansen et al. published in 2010, called "Varieties of Democracy: Interest Groups and Corporatist Committees in Scandinavian Policy Making". In it the authors compared the number of corporatist public committees in Denmark, Norway and Sweden from the 1970s until 2004/2005. By using this measure, they found that corporatism has declined in Scandinavia in recent decades. But they also discovered variations in this development within the individual countries. In the past, for example, Sweden used to be less corporatist in terms of the preparation of policy than Denmark and Norway. Also, although preparatory corporatism has almost disappeared in Denmark and Norway, implementation corporatism is still relatively robust in Denmark.

When Iceland is added to the comparisons an interesting picture emerges. Contrary to developments in Scandinavia, corporatism appears to be stronger today in Iceland 
than it was in 1970 and 1985. In the new century, Iceland has the greatest number of corporatist public committees of the countries compared. One of the interesting findings of this paper is that already in 1970 Iceland was more corporatist, by using the indicator of corporatist public committees, than Sweden. Also, in the mid-1980s Iceland was not far behind Denmark and Norway in terms of the total number of corporatist committees.

The growth of Icelandic corporatist public committees, compared to 1970 and 1985, is due to the explosion in the number of corporatist preparatory public committees, while the number of corporatist implementation committees has not changed much. At the end of 2017 Iceland had 180 corporatist preparatory public committees, compared to 54 in 1970. In this regard, Iceland is in a league by itself among the other Nordic countries included in this study. There, corporatist preparatory committees have mostly disappeared. In terms of implementation corporatism, Denmark probably ranks first among the Nordic countries, followed by Iceland.

All but two of the corporatist implementation committees in Iceland are required by various law, regulations or agreements to include representatives of interest organization. The same applies to a little over a half of the preparatory corporatist public committees. This may be regarded as a further evidence of the institutionalized embeddedness of corporatism in Iceland. But likewise, the high number of ad hoc preparatory committees, that include representatives of interest organizations, is also a clear indication of the embeddedness of corporatist practices. Because even though it does not have to include such representatives, the state finds it useful, or even necessary, to appoint them to committees involved with the various stages of policy preparation. Recalling the arguments made by Öberg et al. (2011), this is likely the result of the fact that various Icelandic interest organizations have the necessary mandate, unity, assets and willingness to participate in corporatist exchanges. Corporatist exchanges are, especially, likely in the fields of education, health, social affairs, environmental issues and within core industrial sectors such as agriculture and the fisheries.

On a final note, the study shows that the functional representational channel is an important feature of Icelandic democracy. In Iceland, interest groups are often integrated into the democratic process of decision-making and implementation in an institutionalized and privileged manner. This is the essence of corporatism, defined as the institutionalized and privileged integration of organized interests in the preparation and/or implementation of public policies.

\section{Acknowledges}

This research was in part supported by a research grant from the Research Fund of the University of Iceland. I would like to thank my research assistant, Gunnlaugur Snær Ólafsson, for assisting me in collecting the data on Icelandic public committees for the year 2017. I also thank Hilmar Rommetvedt for his advice. 


\section{Notes}

1 Siaroff (1999) nominally included Iceland in his comparative study of corporatism in 24 industrial democracies, but lacked sufficient information to rank it (Siaroff 1999, 183).

2 Their study offers more historical data than is yet available for Iceland, but their most recent data only covers 2004/2005. Newer comparative data on the number of Scandinavian public committees is not available in the literature.

3 The opposite of corporatism in policy preparation may be pluralism or the electoral channel of representation, whereas classical bureaucracy is the alternative to corporatism in policy implementation.

4 Binderkrantz and Christiansen $(2015,8)$, however, found 273 corporatist committees in Denmark in 2010. It is not clear whether these are only committees appointed by central government, or not. Nevertheless, the number should be mentioned, despite the fact that it is not included in the study of Christiansen et al. (2010).

5 According to Binderkrantz and Christiansen (2015, 9), Denmark had only three corporatist preparatory committees in 2010.

6 In addition, it should be mentioned, that 14 of the Icelandic corporatist committees were both assigned to preparation of policy and implementation in 2017, see Table 4.

7 Binderkrantz and Christiansen found 270 implementation committees in Denmark in 2010 (Binderkrantz \& Christiansen 2015, 9).

8 Kristinsson (1994) differentiates between interest organizations and local interest groups and municipalities. Here in this paper the percentages for these different categories of interest organizations are added together.

9 This high percentage is due to several public committees concerned with ensuring full employment and labour issues (atvinnumálanefndir). All of them had representatives from interest organizations. In 1985 these types of public committees had moved to other ministries.

10 Iceland did not have a special Ministry of the Environment until 1990s so no historical comparison is yet possible. But in 2017 this ministry had 34 public committees with interest representation. This points to the prevalence of a corporatist approach within the ministry, which also oversees issues relating to natural resources (Umbverfis- og audlindaráduneytid).

11 In addition, there is also, for example, the Icelandic Employers' Federation (Félag atvinnurekenda) that represents companies involved in most types of business and trade, importing, exporting, wholesaling and retail distribution.

12 In the past the state also collected membership dues for other producers' groups, including the Federation of Icelandic Industries (idnaðarmálagjald) and the Federation of Small Boat Owners. The practice was challenged in 2010 when the European Court of Human Rights ruled that it violated the freedom of association to require firms in industry to pay the tax/dues.

\section{References}

Almond, G.A. (1983). "Corporatism, Pluralism, and Professional Memory”, World Politics 35, 245-260.

Armingeon, K. (2002). "Interest Intermediation: The Cases of Consociational Democracy and Corporatism", in H. Keman (ed.), Comparative Democratic Politics. London: Sage.

ASÍ (n.d.). Icelandic Confederation of Labour. Retrived from http://www.asi.is/engpol/

Binderkrantz, A. (2005). "Interest Group Strategies: Navigating Between Privileged Access and Strategies of Pressure", Political Studies 53, 694-715.

Binderkrantz, A., and Christiansen, P.M. (2015). "From Classic to Modern Corporatism. Interest Group Representation in Danish Public Committees in 1975 and 2010", Journal of European Public Policy 22(7), 1022-1039.

Blom-Hansen, J. (2000). "Still Corporatism in Scandinavia? A Survey of Recent Empirical Findings", Scandinavian Political Studies 23, 157-181. 
Blom-Hansen, J. (2001). "Organized Interests and the State. A Disintegrating Relationship? Evidence From Denmark", European Journal of Political Research 39, 391-416.

Cawson, A. (1986). Corporatism and Political Theory. Oxford: Basil Blackwell.

Christiansen, P.M., Nørgaard, A.S., Rommetvedt, H., Svensson, T., Thesen, G., and Öberg, P. (2010). "Varieties of Democracy: Interest Groups and Corporatist Committees in Scandinavian Policy Making", Voluntas: International Journal of Voluntary and Nonprofit Organizations 21(1), $22-40$.

Christiansen, P.M., and Nørgaard, A.S. (2003). Faste Forbold, Flygtige Forbindelser: Stat og Interesseorganisationer $i$ det 20. Arbundrede. Aarhus: Aarhus University Press.

Christiansen, P.M., and Nørgaard, A.S. (2006). "Whose Agents? Non-governmental Organizations in Policy Proposing Commissions: Agents of Government or Opposition Parties?”, in D. Braun and F. Gilardi (eds.), Delegation in Contemporary Democracies. London: Routledge.

Christiansen, P.M., and Rommetvedt, H. (1999). "From Corporatism to Lobbyism? Parliaments, Executives, and Organized Interests in Denmark and Norway", Scandinavian Political Studies 22, 195-220.

Fjárlaga- og hagssýslustofnun (1970-1985). Stjórnir, nefndir og ráð ríkisins, annual reports published for 1970-1985. Reykjavík: Fjárlaga- og hagssýslustofnun.

Guðmundsson, J. (1949). "Ráðstjórn á Íslandi”, Dagrenning 4(6), 3-8.

Hermansson, J., Svensson, T., and Öberg, P. (1997). "Vad Blev det av den Svenske Korporativismen?", Politica 29, 365-384.

Hermansson, J., Svensson, T., and Öberg, P. (1999). Avkorporativisering och Lobbyism. Stockholm: SOU

Indriðason, I.H., and Kristinsson, G.H. (2015). "Primary Consequences: The Effects of Candidate Selection Through Party Primaries in Iceland”, Party Politics 21(4), 565-576.

Jónsson, G. (2014). "Iceland and the Nordic Model of Consensus Democracy", Scandinavian Journal of History 39(4), 510-528.

Kristinsson, G.H. (1994). Embattismenn og stjórnmálamenn: Skipulag og vinnubrögð i íslenskeri stjórnsýslu. Reykjavík. Heimskringla.

Kristinsson, G.H. (2011). "Party Cohesion in the Icelandic Althingi", The Icelandic Review of Politics and Administration 7(2), 229.

Molina, O., and Rhodes, M. (2002). "Corporatism: The Past, Present, and Future of a Concept". Annual Review of Political Science 5(1), 305-331.

Lijphart, A. (1999). Patterns of Democracy: Government Forms and Performance in Thirty-Six Countries. New Haven: Yale University Press.

Lijphart, A. (2002). "Negotiation Democracy Versus Consensus Democracy: Parallel Conclusions and Recommendations”, European Journal of Political Research 41, 107-113.

Lijphart, A., and Crepaz, M.M.L. (1991). "Corporatism and Consensus Democracy in Eighteen Countries: Conceptual and Empirical Linkages”, British Journal of Political Science 21, 235-256.

Rommetvedt, H. (2017). "Scandinavian Corporatism in Decline", in O. Knutsen (ed.), The Nordic Models in Political Science: Challenged but Still Viable?. Bergen: Faboglaget.

Rommetvedt, H., Thesen, G., Christiansen, P.M., and Nørgaard, A.S. "Coping with Corporatism in Decline and the Revival of Parliament: Interest Groups Lobbyism in Denmark and Norway, 19802005", Comparative Political Studies 46(4), 457-485.

Óskarsdóttir, S. (1995). The Use of Incomes Polices: Icelandic Incomes Policies, 1969-1995. Unpublished Ph. D. dissertation. Purdue University, W. Lafayette, Indiana.

Óskarsdóttir, S. (1999). "Metamorfosen af Industriella Relationer", in K. Stålhberg (ed.), Den Nordiska Modellen in en Brytningstid (pp. 81-103). Copenhagen: Nordic Council of Ministers.

Rokkan, S. (1966). "Norway: Numerical Democracy and Corporate Pluralism”, in R.A. Dahl (ed.), Political Oppositions in Western Democracies. New Haven and London: Yale University Press.

SA (n.d.). SA confederation of Icelandic Enterprise. Retrieved from http://sa.is/sa-confederation-of-icelandic-enterprise

Schmitter, P. (1974). "Still a Century of Corporatism?”, The Review of Politics 36(1), 85-13. 
Siaroff, A. (1999). "Corporatism in 24 Industrial Democracies: Meaning and Measurement", European Journal of Political Research 36, 175-205.

Thesen, G., and Rommetvedt H. (2009). "Norske Organisasjoners Strategier for Politisk Innflytelse”, in B. Enjolras and R.H. Waldahl (eds.), Frivilige Organissjoner og Offentlig Polititike.k. Oslo. Novus Forlag. Thorhallsson, B. (2010). "The Corporatist Model and its Value in Understanding Small European States in the Neo-liberal World of the Twenty-first Century: The Case of Iceland", European Political Science 9(3), 375-386.

Öberg, P.O., Svensson, T., Christiansen, P.M., Nørgaard, A.S., Rommetvedt, H., and Thesen, G. (2011). "Disrupted Exchange and Declining Corporatism: Government Authority and Interest Group Capability in Scandinavia", Government and Opposition 46(3), 365-391. 